\title{
Program för näringspolitik
}

Sveriges ordförandeskap 2018

10 Nordiska ministerrådet 


\section{Program för näringspolitik}

Sveriges ordförandeskap 2018 i Nordiska ministerrådet

ANP 2017:783

ISBN 978-92-893-5271-O (PRINT)

ISBN 978-92-893-5272-7 (PDF)

ISBN 978-92-893-5273-4 (EPUB)

http://dx.doi.org/10.6027/ANP2017-783

(c) Nordiska ministerrådet 2017

Layout: Gitte Wejnold

Omslagsfoto: Unsplash.com

\section{Det nordiska samarbetet}

Det nordiska samarbetet är ett av världens mest omfattande regionala samarbeten. Det omfattar Danmark, Finland, Island, Norge och Sverige samt Färöarna, Grönland och Åland.

Det nordiska samarbetet är politiskt, ekonomiskt och kulturellt förankrat och en viktig del av europeiskt och internationellt samarbete. Den nordiska gemenskapen arbetar för ett starkt Norden i ett starkt Europa.

Det nordiska samarbetet vill styrka nordiska och regionala intressen och värderingar i en global omvärld. Gemensamma värderingar länderna emellan bidrar till att stärka Nordens ställning som en av världens mest innovativa och konkurrenskraftiga regioner.

\section{Nordiska ministerrådet}

Nordens Hus

Ved Stranden 18

1061 København $\mathrm{K}$

www.norden.org

Ladda ner nordiska publikationer: www.norden.org/nordpub 
Sverige kommer under sitt ordförandeskap i Nordiska ministerrådet 2018 att ha inriktning på Agenda 2030 och digitalisering. Inom näringssektorn kommer ett brett grepp tas på de frågor som påverkar våra gemensamma förutsättningar för innovation, jobb och tillväxt i Norden.

Det huvudsakliga verktyget för att genomföra detta är det nya nordiska samarbetsprogrammet för närings- och innovationspolitik 2018-2021.

Sverige vill inom närings- och innovationsområdet uppmärksamma de möjligheter som digitaliseringen innebär såväl för samhället som för näringslivet, med särskilt fokus på små- och medelstora företag.

Detta omfattar en bredd av områden som $t$ ex testbäddar, automation, digitaliserade affärsmodeller och besöksnäringen, men även IT-infrastruktur och tjänster, smart och hållbart byggande samt ett transporteffektivt samhälle.

Andra viktiga frågor är samarbete kring implementering av EU-direktiv och innovationsupphandling. Det finns även stor potential att utnyttja de satsningar som görs kring etableringen av forskningsinfrastrukturerna ESS och Max IV.
Tillgång till bredband är snart en förutsättning för att kunna ta del av grundläggande samhällsservice och att fullt ut vara delaktig i samhället. Den utvecklingen har redan kommit långt. Digitaliseringen kommer också att kunna bidra till en omfattande effektivisering av det offentliga, en förbättrad samhällsservice och bättre livskvalitet för medborgarna. Men för att alla människor ska kunna ta del av samhällsservice på ett jämlikt sätt, för att framgångsrika företag ska kunna utvecklas $i$ alla delar av landet och för att det offentliga ska kunna effektivisera servicen till invånarna måste alla ha säker och snabb tillgång till internet.

Urbanisering, den demografiska utvecklingen och klimatförändringar innebär utmaningar inom bl.a. nordisk stads- och samhällsutveckling. Gränsöverskridande samarbeten och på sikt en mer integrerad byggmarknad med ökad harmonisering av nordiska byggregelverk främjar god konkurrenskraft, möjligheter för gemensamma nordiska lösningar och affärsmodeller och utveckling av hållbart byggande i exempelvis trä.

Det nordiska samarbetet kan också bidra till ett mer transporteffektivt samhälle där transporterna används smartare och med mer resurseffektiva fordon, förnybara bränslen och mindre utsläpp. 


\section{Det nordiska samarbetsprogrammet för närings- och innovationspolitik 2018-2021}

Samarbetsprogrammet fokuserar på tre områden där de nordiska ekonomierna står för gemensamma utmaningar men samtidigt har potential att vara globalt starka genom att samarbeta.

1. Säkerställa en förmåga till snabb omställning

Nordiskt samarbete om att möta teknologiska förändringar

Digitalisering och nya gröna affärsmodeller

2. Stärka innovations- och konkurrenskraften

Det offentliga som drivkraft för innovation

Bättre tillgång till riskkapital över landsgränserna

3. Förbättra globala marknadsmöjligheter

Norden som globalt innovationsnav

Samarbete på internationella marknader

Dessa tre områden ligger i linje med och förstärker regeringens satsningar på bland annat Samverkansprogrammen, Smart industri, Digitaliseringsstrategin och Exportstrategin, samt det övergripande arbete som sker inom Agenda 2030. Genom programmet så möjliggörs ny kunskap, samarbeten och ökad gränsöverskridande handel för svenska företag, myndigheter och organisationer. 


\section{Ministermöten}

Under ordförandeskapet kommer tre ministermöten hållas inom Näringssektorn.

- IT-ministermöte i Stockholm 14 maj 2018

- Näringsministermöte i Stockholm 15 maj 2018

- Bostadsministermöte i Stockholm 29 maj 2018

Näringssektorn medverkar i följande tre ordförandeprojekt som löper 2018-2020:

- Klimatsmarta stadstransporter, tillsammans med Miljösektorn

- Hållbart byggande genom nordisk gestaltning och träbyggande, tillsammans med Kultursektorn

- E-hälsa och vård på distans, tillsammans med Socialsektorn och Regionalsektorn

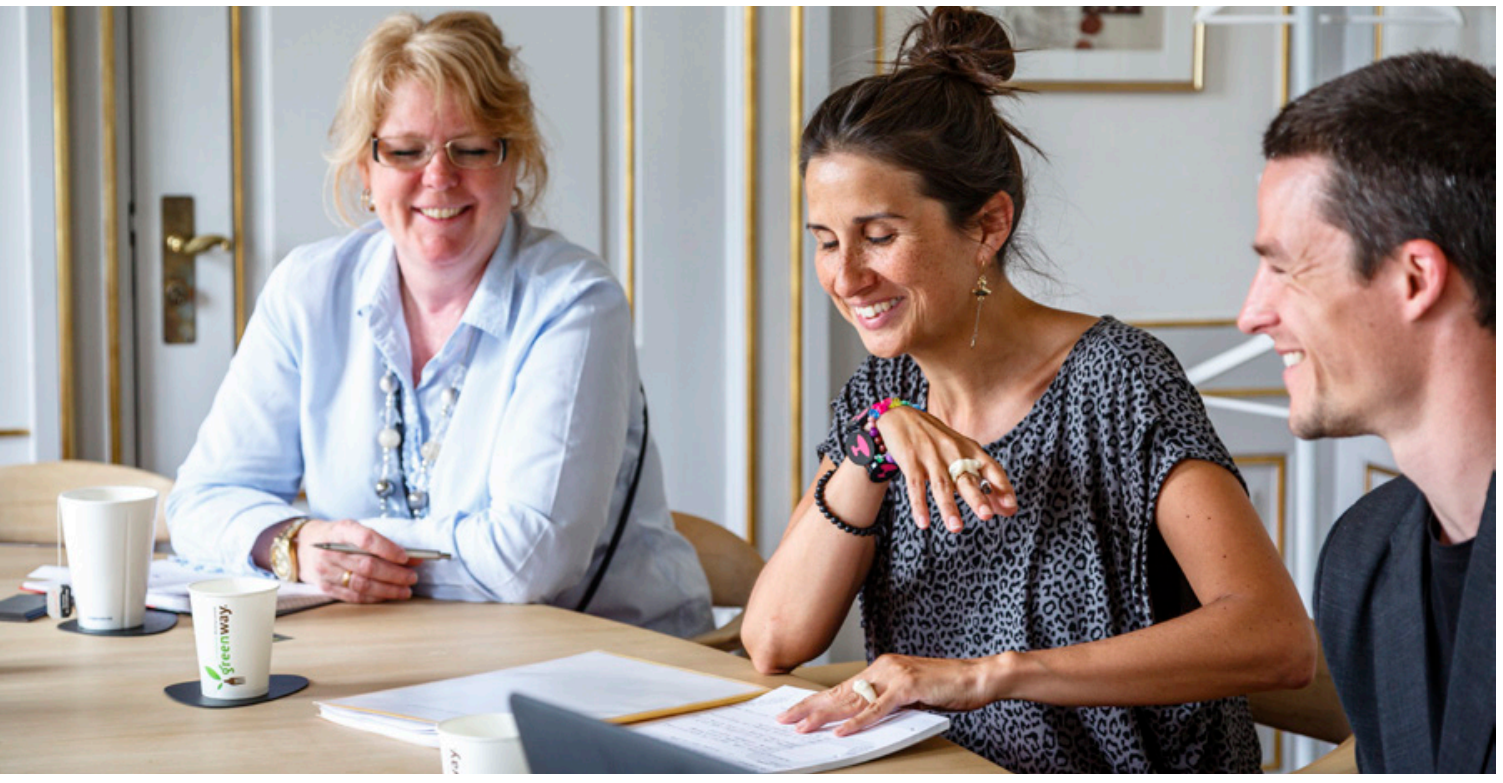




\section{$\mathbb{1}$}

Nordisk ministerråd

Nordens Hus

Ved Stranden 18

DK-1061 København K

www.norden.org

Sverige kommer under sitt ordförandeskap i Nordiska

ministerrådet 2018 att ha inriktning på Agenda 2030 och

digitalisering. Inom näringssektorn kommer ett brett grepp tas på de frågor som påverkar våra gemensamma förutsättningar för innovation, jobb och tillväxt i Norden. Det huvudsakliga verktyget för att genomföra detta är det nya nordiska samarbetsprogrammet för närings- och innovationspolitik 2018-2021. 